\title{
Effect of integrated nutrient management on nutrient uptake and economics of fertilizer use in rice cv. NERICA 10
}

\author{
K. Ghosh*, M. A. H. Chowdhury, M. H. Rahman ${ }^{1}$ and S. Bhattacherjee \\ Department of Agricultural Chemistry, Bangladesh Agricultural University, Mymensingh-2202, and ${ }^{1}$ Soil Science \\ Division, Bangladesh Institute of Nuclear Agriculture, Mymensingh, Bangladesh, *Email : ghoshkuntala@ymail.com
}

\begin{abstract}
The integrated use of chemical and organic fertilizers can help in sustainable and environmentally sound nutrient management of soils. A study was conducted in the farmer's field of Godaghari, Rajshahi from February to May 2012 to investigate the effect of integrated nutrient management on nutrient uptake by rice cV. NERICA 10 and economization of inputs. Six treatments viz. $T_{1}=$ Control, $T_{2}=$ RFD for MYG + cowdung @ $5 \mathrm{t} \mathrm{ha}^{-1}, \mathrm{~T}_{3}=\mathrm{RFD}$ for HYG, $T_{4}=$ RFD for HYG + cowdung @ $5 \mathrm{t} \mathrm{ha}^{-1}, \mathrm{~T}_{5}=$ RFD for HYG + cowdung @ $5 \mathrm{t} \mathrm{ha}^{-1}$ based on IPNS, and T $6=$ RFD for HYG + 10\% excess fertilizer of HYG were used. The experiment was laid out in a randomized complete block design with three replications. Results showed that the uptake of $\mathrm{N}, \mathrm{P}, \mathrm{K}, \mathrm{S}, \mathrm{Ca}$ and $\mathrm{Mg}$ by both grain and straw of rice were statistically significant due to use of integrated nutrient management. The highest nutrient uptake was recorded from the treatment $T_{5}$ and the lowest value was obtained from control. Combined application of cowdung @ $5 \mathrm{t} \mathrm{ha}^{-1}$ along with recommended chemical fertilizers based on IPNS was more economic compared to other treatments because maximum benefit cost ratio was calculated from this treatment. The overall results suggest that integrated nutrient management can be used as an alternate option of chemical fertilization to achieve maximum yield, nutrient uptake and cost of return for rice cv. NERICA 10 cultivation.
\end{abstract}

Keywords: Rice, Integrated nutrient management, Nutrient uptake, Benefit cost ratio

\section{Introduction}

Integrated nutrient management (INM) is very important in rice production. Many of our problems on declining productivity (increasing cost, decreasing yield) can be traced to improper and inefficient use of nutrients. Improper nutrient management has resulted in nutrient imbalances in the soil with nutrients in excess while other nutrients depleted. Through this, farmers can increase agricultural productivity and safeguard the environment as they use fertilizer efficiently. Rice (Oryza sativa $\mathrm{L}$ ) is the most extensively cultivated cereal crop in Bangladesh, which covers about $74 \%$ of the total cropped area (BBS, 2011). In respect of area and production of rice, Bangladesh ranks fourth following China, India and Indonesia (FAO, 2008). NERICA 10 is a moderately stress tolerant and high yielding variety of rice in Africa. The progeny was developed by West Africa Rice Development Association (WARDA), combining traits from the hardy African rice resistant to pests, weeds and problematic soils with the high yielding, good response to mineral fertilization and non-shattering characteristics of the Asian rice (Dzomeku et al., 2007; Kijima et al., 2006; WARDA, 2001). The interspecific hybridization programme used by WARDA to breed a range of new rice varieties, which have been given the name New Rice for Africa (NERICA). The application of chemical fertilizers is costly and gradually lead to the environmental problems. Organic residue recycling is becoming an important aspect of environmentally sound sustainable agriculture. Nowa-days, agriculture production based on organic applications is growing interest and the demands for the resulting products are increasing. Therefore, the effective use of organic materials in rice farming is also likely to be promoted. The application of organic materials is fundamentally important in that they supply various kinds of plant nutrients including micronutrients, improve soil physical and chemical properties and hence nutrient holding and buffering capacity and consequently enhance microbial activities (Suzuki, 1997). Thus, it is necessary to know the potential of nutrient release, uptake and accumulation in plants. Therefore, this study was undertaken to evaluate the effect of integrated nutrient management on the nutrient uptake by rice cv. NERICA 10. 


\section{Materials and Methods}

The study was carried out during Boro season of 2012 in the farmer's field at Chaighati, Godaghari, Rajshahi. There were six treatments combination viz $\mathrm{T}_{1}$ (control), $\mathrm{T}_{2}$ (RFD for MYG + cowdung @ $5 \mathrm{t}$ $\mathrm{ha}^{-1}$ ), $\mathrm{T}_{3}$ (RFD for HYG), T (RFD for HYG + cowdung @ $5 \mathrm{t} \mathrm{ha}^{-1}$ ), $\mathrm{T}_{5}$ (RFD for HYG + cowdung @ $5 \mathrm{t}$ ha $^{-1}$ based on IPNS) and $T_{6}$ (RFD for HYG $+10 \%$ excess fertilizer of HYG). The experiment was laid out in a randomized complete block design with three replications. The soil was silt loam texture having $\mathrm{pH}$ 5.4 , organic matter $1.25 \%$, total $\mathrm{N} 0.09 \%$, available $\mathrm{P} 8 \mu \mathrm{g} \mathrm{g}{ }^{-1}$ soil, exchangeable $\mathrm{K} 0.11 \mathrm{cmol} \mathrm{kg}^{-1}$, available $S 9 \mu \mathrm{g} \mathrm{g}^{-1}$ soil determined by the method described by Jackson (1973); Page et al. (1982); and Black, (1965). Recommended doses from urea $\left(120 \mathrm{~kg} \mathrm{~N} \mathrm{ha}^{-1}\right)$, TSP $\left(25 \mathrm{~kg} \mathrm{P} \mathrm{ha}^{-1}\right)$ MoP $\left(65 \mathrm{~kg} \mathrm{~K} \mathrm{ha}^{-1}\right)$, boric acid $\left(1 \mathrm{~kg} \mathrm{~B} \mathrm{ha}^{-1}\right)$, zinc oxide $\left(3 \mathrm{~kg} \mathrm{Zn} \mathrm{ha}^{-1}\right)$ and cowdung $\left(5 \mathrm{t} \mathrm{ha}^{-1}\right)$ were applied. One third of $\mathrm{N}$ and full doses of $\mathrm{P}, \mathrm{K}, \mathrm{S}, \mathrm{Zn}$ and $\mathrm{B}$ were applied at the time of final land preparation and remaining $\mathrm{N}$ was applied in early tillering and late tillering stage. Cowdung was incorporated into soil 7 days before transplanting. Thirty day old seedlings were transplanted on 12 February 2012. Weeding and irrigation were done as and when necessary throughout the growing period. Plants were harvested when attained full maturity. The rice grain and straw were collected in the laboratory and $\mathrm{N}, \mathrm{P}, \mathrm{K}, \mathrm{S}, \mathrm{Ca}$ and $\mathrm{Mg}$ contents were determined by semi-micro kjeldahl method (Jackson, 1973 and Page et al., 1982), spectrophotometric method (Page et al., 1982), flame emission spectrophotometric method (Ghosh et al., 1983), turbidimetric method and EDTA titrimetric method (Page et al., 1982) respectively. Analysis of variance was done with the help of computer package program MSTAT-C according to Gomez and Gomez (1984) and the mean differences among different treatments were adjudged by DMRT.

\section{Results and Discussion}

\section{Effect of cowdung and chemical fertilizers on nutrient uptake by rice}

Nitrogen: Results in Table 1 indicated that the $N$ uptake varied significantly due to the renewed application of chemical fertilizers and organic manures. The highest $\mathrm{N}$ uptake $\left(99.69 \mathrm{~kg} \mathrm{ha}^{-1}\right)$ was recorded in the treatment $T_{5}$ (RFD for HYG + cowdung @ $5 \mathrm{t} \mathrm{ha}^{-1}$ based on IPNS) which was significantly different from all other treatments. This result was similar to the result of Bhadoria and Prokash (2003). The lowest $\mathrm{N}$ uptake $\left(43.49 \mathrm{~kg} \mathrm{ha}^{-1}\right.$ ) was noted in the treatment $\mathrm{T}_{1}$ (control). Jacqueline et al. (2008) reported that the $\mathrm{N}$ uptake by rice grain and straw increased significantly with the combined application of organic manure and chemical fertilizers. Results revealed that application of compost in combination with fertilizers significantly increased the $\mathrm{N}$ uptake by rice plant over control.

Phosphorus: Phosphorus uptake of NERICA rice was significantly influenced due to various treatments used in the experiment (Table 1). The highest $P$ uptake $\left(24.47 \mathrm{~kg} \mathrm{ha}^{-1}\right)$ was recorded in the treatment $T_{5}$ (RFD for HYG + cowdung @ $5 \mathrm{t} \mathrm{ha}^{-1}$ based on IPNS) which was significantly different from all other treatments. Similar findings were also found by Moula (2005) who reported that nutrient content as well as nutrient uptake by rice over other treatments due to combined application of organic and inorganic fertilizers. The lowest value of $P$ uptake $\left(10.71 \mathrm{~kg} \mathrm{ha}^{-1}\right)$ was noted in the treatment $T_{1}$ (control) which was statistically different from all other treatments. Zhang et al. (1998) reported that organic manures increased labile, moderately stable and stable organic $\mathrm{P}$ contents in soil and uptake by plants.

Potassium: Uptake of $\mathrm{K}$ significantly influenced due to the application of chemical fertilizers and organic manures (Table 1). The highest $\mathrm{K}$ uptake $\left(115.15 \mathrm{~kg} \mathrm{ha}^{-1}\right)$ was recorded in the treatment $\mathrm{T}_{6}$ (RFD for HYG $+10 \%$ excess fertilizer of HYG) which was statistically identical to the treatment $T_{5}$ (RFD for HYG + cowdung@ 5 t ha $^{-1}$ based on IPNS). Bhadoria and Prokash (2003) observed significantly greater K uptake by rice plants using organic manures in combination with chemical fertilizers. Combined application of organic materials (rice straw and banana plant residue) and fertilizers at different doses increased significantly the $\mathrm{K}$ uptake by rice grain over application of fertilizers at $100 \%$ recommended dose or organic material alone. The lowest value of $\mathrm{K}$ uptake $\left(45.14 \mathrm{~kg} \mathrm{ha}^{-1}\right)$ was noted in the treatment $\mathrm{T}_{1}$ (control) which was statistically different from all other treatments. These results were in agreement with the findings of Sreelatha et al. (2006) who reported that application of organic manure and chemical fertilizers significantly increased the $\mathrm{K}$ uptake by rice. 
Sulphur: Sulphur uptake by NERICA 10 rice was significantly influenced by various treatments (Table 2). The highest $S$ uptake $\left(11.96 \mathrm{~kg} \mathrm{ha}^{-1}\right.$ ) was recorded in the treatment $\mathrm{T}_{6}$ (RFD for HYG $+10 \%$ excess fertilizer of HYG) which was statistically identical to the treatments $\mathrm{T}_{4}$ (RFD for HYG + cowdung @ $5 \mathrm{t}$ $\mathrm{ha}^{-1}$ ). These results were in agreement with the findings of Poongothai et al. (1999) who observed that application of $S$ significantly enhanced $S$ uptake by rice. The lowest value of $S$ uptake $\left(4.67 \mathrm{~kg} \mathrm{ha}^{-1}\right)$ was noted in the treatment $T_{1}$ (control) which was statistically different from all other treatments. Results revealed that the combined application of organic fertilizer and chemical fertilizers exerted better performance on the uptake of S by NERICA 10. Azim et al. (1999) also recorded higher uptake of S with the application of manures and fertilizers either alone or in combinations.

Calcium: Uptake of Ca significantly influenced due to the application of chemical fertilizers and organic manures (Table 2). The highest Ca uptake $\left(42.9 \mathrm{~kg} \mathrm{ha}^{-1}\right)$ was recorded in the treatment $T_{5}=$ RFD for HYG + cowdung @ $5 \mathrm{t} \mathrm{ha}^{-1}$ based on IPNS which was different with the other treatments. The lowest value of Ca uptake (11.77 kg ha-1) was noted in the treatment $T_{1}$ (control) which was statistically different from all other treatments. It indicates that the recommended fertilizer dose had significant effect on Ca content in both grain and straw. The results of our study was supported by the findings of Blum et al. (2003) who reported that application of $\mathrm{Ca}$ significantly enhanced uptake by squash fruit with the addition of farm yard manure. Use of chemical fertilizers all the nutrients were present in balanced proportion, it might be responsible for increasing the $\mathrm{Ca}$ uptake by rice.

Magnesium: The result indicated that significant variation were found in Mg uptake by rice (Table 2). The highest Mg uptake (59.67 kg ha ${ }^{-1}$ ) was recorded in the treatment $T_{5}$ (RFD for HYG + cowdung @ $5 \mathrm{t} \mathrm{ha}^{-1}$ based on IPNS) which was different with the other treatments. The lowest value of total Mg uptake (19.41 $\mathrm{kg} \mathrm{ha}^{-1}$ ) was noted in the treatment $\mathrm{T}_{1}$ (control) which was statistically different from all other treatments. A similar result was obtained by Blum et al. (2003) who found that application of farm yard manure increased $\mathrm{Mg}$ uptake by squash fruit. Use of chemical fertilizers all the nutrients were present in balanced proportion, it might be responsible for increasing the $\mathrm{Mg}$ uptake by rice.

Table 1. Effects of integrated nutrient management on $\mathrm{N}, \mathrm{P}$ and $\mathrm{K}\left(\mathrm{kg} \mathrm{ha}^{-1}\right)$ uptake by rice cv. NERICA 10

\begin{tabular}{|c|c|c|c|}
\hline Treatment & N uptake & P uptake & K uptake \\
\hline $\mathrm{T}_{1}$ & $43.49 \mathrm{~d}$ & $10.71 \mathrm{c}$ & $45.14 \mathrm{c}$ \\
\hline $\mathrm{T}_{2}$ & $73.28 \mathrm{c}$ & $17.81 \mathrm{~b}$ & $87.50 \mathrm{~b}$ \\
\hline $\mathrm{T}_{3}$ & $88.86 \mathrm{abc}$ & $18.64 \mathrm{~b}$ & $108.66 \mathrm{ab}$ \\
\hline $\mathrm{T}_{4}$ & $79.81 \mathrm{bc}$ & $16.28 \mathrm{~b}$ & $97.23 \mathrm{ab}$ \\
\hline $\mathrm{T}_{5}$ & $99.69 \mathrm{a}$ & $24.47 \mathrm{a}$ & $114.26 \mathrm{a}$ \\
\hline $\mathrm{T}_{6}$ & $96.98 \mathrm{ab}$ & $23.08 \mathrm{a}$ & $115.15 \mathrm{a}$ \\
\hline $\mathrm{CV} .(\%)$ & 11.85 & 5.60 & 12.70 \\
\hline
\end{tabular}

Table 2. Effects of integrated nutrient management on $\mathrm{S}, \mathrm{Ca}$ and $\mathrm{Mg}\left(\mathrm{kg} \mathrm{ha}^{-1}\right)$ uptake by rice $\mathrm{cv}$. NERICA 10

\begin{tabular}{|c|c|c|c|}
\hline Treatment & S uptake & Ca uptake & Mg uptake \\
\hline $\mathrm{T}_{1}$ & $4.67 \mathrm{~d}$ & $11.77 \mathrm{c}$ & $19.41 \mathrm{c}$ \\
\hline $\mathrm{T}_{2}$ & $7.45 \mathrm{c}$ & $29.68 \mathrm{~b}$ & $39.54 \mathrm{~b}$ \\
\hline $\mathrm{T}_{3}$ & $9.72 \mathrm{~b}$ & $38.3 \mathrm{ab}$ & $52.77 \mathrm{ab}$ \\
\hline $\mathrm{T}_{4}$ & $11.31 \mathrm{ab}$ & $32.00 \mathrm{~b}$ & $45.73 \mathrm{~b}$ \\
\hline $\mathrm{T}_{5}$ & $11.39 \mathrm{ab}$ & $42.90 \mathrm{a}$ & $59.67 \mathrm{a}$ \\
\hline $\mathrm{T}_{6}$ & $11.96 \mathrm{a}$ & $37.73 \mathrm{ab}$ & $53.13 \mathrm{ab}$ \\
\hline $\mathrm{CV} .(\%)$ & 3.41 & 9.34 & 9.83 \\
\hline
\end{tabular}

Legend: $T_{1}=$ control , $T_{2}=$ RFD for MYG + cowdung @ $5 \mathrm{t} \mathrm{ha}^{-1}, \mathrm{~T}_{3}=$ RFD for HYG, $\mathrm{T}_{4}=\mathrm{RFD}$ for HYG + cowdung @ $5 \mathrm{t}$ ha ${ }^{-1}$, $\mathrm{T}_{5}=$ RFD for HYG + cowdung @ $5 \mathrm{t} \mathrm{ha}^{-1}$ based on IPNS, $\mathrm{T}_{6}=$ RFD for HYG $+10 \%$ excess fertilizer of HYG .

Fertilizer dose (MYG): $\mathrm{N}_{98} \mathrm{P}_{20} \mathrm{~K}_{50} \mathrm{~S}_{15} \mathrm{Zn}_{2} \mathrm{~B}_{1}$ and (HYG): $\mathrm{N}_{120} \mathrm{P}_{25} \mathrm{~K}_{65} \mathrm{~S}_{20} \mathrm{Zn}_{3} \mathrm{~B}_{1}$

In a column having common letters do not differ significantly at $1 \%$ level of

significance. $\mathrm{CV} .=$ Coefficient of variance

276

Effect of integrated nutrient management use in rice 


\section{Economics of fertilizer use}

NERICA 10 rice fertilized with cowdung and inorganic fertilizers separately performed variably in case of both net return and benefit cost ratio (Table 3). Gross return was calculated as the total value of grain and straw yield of rice. Data in Table 3 showed the cost and benefit of different treatments used in the experiment. The highest gross margin of Tk. 85,040 ha ${ }^{-1}$ was obtained in treatment $T_{5}$. Among the treatments, $T_{5}$ treatment gave the highest marginal benefit cost ratio (10.69). The second highest benefit-cost ratio was found in treatment $\mathrm{T}_{4}(8.97)$. The minimum benefit-cost ratio was found in treatment $\mathrm{T}_{2}$.

Table 3. Economic analysis of rice cv. NERICA 10 using different treatments

\begin{tabular}{|c|c|c|c|c|c|c|c|}
\hline \multirow[t]{2}{*}{ Treatment } & \multicolumn{2}{|c|}{$\begin{array}{l}\text { Economic yield } \\
\left(\mathrm{kg} \mathrm{ha}^{-1}\right)\end{array}$} & Gross return & Variable cost & Gross margin & $\begin{array}{c}\text { Marginal } \\
\text { gross margin }\end{array}$ & \multirow[t]{2}{*}{ MBCR } \\
\hline & Grain & Straw & \multicolumn{4}{|c|}{$\left(\right.$ Tk. ha $\left.{ }^{-1}\right)$} & \\
\hline $\mathrm{T}_{1}$ & 1680 & 2040 & 27240 & - & 27240 & - & - \\
\hline $\mathrm{T}_{2}$ & 3290 & 4270 & 53620 & 4452 & 49168 & 21928 & 4.92 \\
\hline$T_{3}$ & 4420 & 4910 & 71210 & 4576 & 66634 & 39394 & 8.60 \\
\hline $\mathrm{T}_{4}$ & 4530 & 5070 & 73020 & 4590 & 68430 & 41190 & 8.97 \\
\hline $\mathrm{T}_{5}$ & 5290 & 5690 & 85040 & 4943 & 80097 & 52857 & 10.69 \\
\hline$T_{6}$ & 4750 & 5370 & 76620 & 5062 & 71558 & 44318 & 8.75 \\
\hline
\end{tabular}

Legend:

Grain = Tk. $15 \mathrm{~kg}^{-1} ;$ Straw = Tk. $1 \mathrm{~kg}^{-1} ; \mathrm{N}=$ Tk. $20 \mathrm{~kg}^{-1} ; \mathrm{P}=\mathrm{Tk} .22 \mathrm{~kg}^{-1} ; \mathrm{K}=\mathrm{Tk} .25 \mathrm{~kg}^{-1} ; \mathrm{S}=\mathrm{Tk} .10 \mathrm{~kg}^{-1} ; \mathrm{MBCR}=$ Marginal benefit cost ratio.

$\mathrm{T}_{1}=$ control, $\mathrm{T}_{2}=\mathrm{RFD}$ for MYG + cowdung @ $5 \mathrm{t} \mathrm{ha}^{-1}, \mathrm{~T}_{3}=$ RFD for HYG, $\mathrm{T}_{4}=$ RFD for HYG + cowdung @ $5 \mathrm{tha}{ }^{-1}, \mathrm{~T}_{5}=\mathrm{RFD}$ for HYG + cowdung @ $5 \mathrm{t} \mathrm{ha}^{-1}$ based on IPNS , $\mathrm{T}_{6}=$ RFD for HYG $+10 \%$ excess fertilizer of HYG

\section{Conclusion}

From the result of this study, it may be concluded that integrated nutrient management increased $\mathrm{N}, \mathrm{P}, \mathrm{K}$, $\mathrm{S}, \mathrm{Ca}$ and $\mathrm{Mg}$ uptake by rice cv. NERICA 10. The overall results suggest that cowdung @ $5 \mathrm{t} \mathrm{ha-1}$ along with recommended chemical fertilizers based on IPNS can be practised for increasing nutritional quality and economic benefit of rice cV. NERICA 10 in the drought prone areas of Rajshahi.

\section{References}

Azim, S.M.A., Rahman, M.M., Islam, M.R. and Hoque, M.A. 1999. Effect of sulphur, zinc and boron supplied from manures and fertilizers on yield and nutrient uptake by rice Progress Agriculture. 10(1\&2) : 87-90.

BBS 2011. Statistical Year Book of Bangladesh. Statistical Division Ministry of Planning, Govt. Peoples Republic Bangladesh, Dhaka, p. 37.

Bhadoria, P.B.S., Prokash, Y.S. 2003. Relative influence of organic manures in combination with chemical fertilizer in improving rice productivity of lateritic soil, Journal of Sustainable Agriculture. 23(1) 77-87.

Black, C.A. 1965. Methods of Soil Analysis Part-I and Part-II. American Society of Agronomy, Madison, Wisconsin, USA. pp. 770.

Blum, L.A.B., Amarante, C.C.T Guttler., G., Macedo, A.F. de., Kothe, D. M., Simmler, A.O., Prado, G., do and Guimarses, L.S. 2003. Production of squash and cucumber in soil amended with poultry manure and pine bark. Horticulture Brasileira, 21 (4) : 627-631.

Dzomeku, I.K., Dogbe, W. and Agawu, E.T. 2007. Responses of NERICA rice varieties to weed interference in the Guinea savannah uplands. J. Agro., $6: 262-269$.

FAO. 2008. Production year book. Food and Agriculture Organization of the United Nations Rome, Italy. p. 57.

Ghosh, A.B., Bajaj, J.C., Hasan, R. and Singh, D. 1983. Soil and Water Testing Method. A Laboratory Manual, Division of Soil Science and Agricultural Chemistry, IARI, New Delhi, India. p. 221-226.

Gomez, K.A. and Gomez, A.A. 1984. Statistical Procedure for Agricultural Research. International Rice Research Institute. The Philippines.

Gomez, K.A. and Gomez, A.A. 1984. Statistical Procedure for Agricultural Research. International Rice Research Institute. The Philippines.

Ghosh et al. 
Hasan, M.M., Chowdhury, M.A.H., Saha, B.K. and Islam, M.R. 2013. Influence of phosphorus and sulphur on yield, yield attributes and biochemical composition of brinjal. Journal of agroforestry and environment. (accepted).

Jackson, M.L. 1973. Soil Chemical Analysis. Prentice Hall of India Pvt. Ltd., New Delhi. p. 151-154.

Jacqueline, A., Prudente, A., Gilbert, C., Sigua, M., Manoch, K. and Alfredo, D. 2008. Improving yield and nutrient uptake potentials of Japonica and Indica rice varieties with nitrogen fertilization. Journal of Agricultural Science 4(4) 427-434.

Kijima, Y., Sserunkuuma, D. and Otsuka, K. 2006. How revolutionary is the "NERICA revolution"? Evidence from Uganda. Dev. Econ. 44:252- 267.

Moula, S.M. 2005. Comparative performance of rock phosphate and TSP on T. Aman rice in Old Brahmaputra Flood Plain and Old Himalayan Piedmont plain soils, MS Thesis, Department of Soil Science, Bangladesh Agricultural University, Mymensingh.

Page, A.L., Miller, R.H. and Keeney, D.R. 1982. Methods of Soil Analysis, Part-2. $2^{\text {nd }}$ Edn. American. Soc. Agron. Inc. Madison, Washington, USA. p. 98-765.

Poongothi, S., Savithri, P., Vennila, R.K. and Bijujosheph, R. 1999. Influence of gypsum and green leaf manure application on rice. Indian Journal of Soil Science Society 47(1): 96-99.

Sreelatha, T., Raju, A.S. and Raju, A.P. 2006. Effect of different doses of farm yard manure and poultry manure and their interaction with fertilizer nitrogen on yield and nutrient uptake in mesta-rice cropping system. Journal of Crop Research 34 41-47.

Suzuki, A. 1997. Fertilization of rice in Japan. Japan FAO Association, Tokyo, Japan

West Africa Rice Development Association (WARDA). 2001. "NERICA Rice for Life."http://www.warda.org/publications/ NERICA8.

Zhang, Y.L., Shen, Q.R. and Cao, C.Y. 1998. Effects of organic manure on soil organic phosphorus functions and their bioavailability. Journal of Nanjing Agricultural University 21(3) 59-63 